\title{
Interaction of plant amine oxidases with diaminoethers
}

\author{
Marek Šebela ${ }^{a},{ }^{*}, K_{\text {Karla Jarkovskáa }}{ }^{\text {, René Lenobel }}{ }^{\mathrm{b}}$, Rosaria Medda ${ }^{\mathrm{c}}$, Alessandra Padiglia ${ }^{\mathrm{c}}$, \\ Giovanni Floris, ${ }^{c}$ and Pavel Peč ${ }^{\mathrm{a}}$
}

${ }^{a}$ Department of Biochemistry, Faculty of Science, Palacký University, Šlechtitelu 11, CZ-783 71

Olomouc, Czech Republic; ${ }^{b}$ Laboratory of Growth Regulators, Palacký University and Institute of Experimental Botany - Czech Academy of Sciences, Šlechtiteli 11, 78371 Olomouc, Czech

Republic; ${ }^{c}$ Department of Applied Sciences in Biosystems, University of Cagliari, I-09042

Monserrato (CA), Italy

E-mail: marek.sebela@upol.cz

\section{Dedicated to Prof. Atta-ur-Rahman on the occasion of his $65^{\text {th }}$ birthday}

\begin{abstract}
Polyamines are ubiquitous compounds, which are involved in crucial physiological events including cell growth and differentiation. The catabolic oxidative degradation of polyamines is catalyzed by quinoprotein copper-containing amine oxidases (CAOs) and flavoprotein polyamine oxidases (PAOs). Various synthetic polyamine analogs and polyamine derivatives have been reported, which represent important tools (substrates or inhibitors) in the study of catalytic properties of the enzymes. In this work, two related compounds were studied in the reactions with plant amine oxidases: 1,8-diamino-3,6-dioxaoctane (DADO) and 1,10-bis(2pyridinylmethyl)-4,7-dioxa-1,10-diazadecane (BPDD). Based on activity and stoichiometry assays together with spectrophotometric measurements, DADO can be considered a good substrate for grass pea, lentil and $E$. characias CAOs with $K_{\mathrm{m}}$ values in the range $10^{-4}-10^{-3} \mathrm{M}$. Its oxidative degradation produces the corresponding aminoaldehyde 8-amino-3,6-dioxaoctanal, which does not undergo spontaneous cyclization (as it is known for the oxidation products of natural substrates putrescine, cadaverine and spermidine) or polymerization in the reaction mixture. Conversely, oat PAO does not oxidize DADO and is only weakly inhibited by the compound $\left(K_{\mathrm{i}}=1.6 \mathrm{mM}\right.$ towards putrescine). BPDD was found to be a competitive inhibitor of both CAOs and PAOs with $K_{\mathrm{i}}$ values of $10^{-4} \mathrm{M}$. DADO could be suggested as a potential affinity ligand for CAOs.
\end{abstract}

Keywords: Diamine oxidase, diaminoether, inhibition, polyamine oxidase, substrate

Abbreviations: BPDD, 1,10-bis(2-pyridinylmethyl)-4,7-dioxa-1,10-diazadecane; CAO, copper amine oxidase; DADO, 1,8-diamino-3,6-dioxaoctane; ELAO; Euphorbia characias amine 
oxidase; GPAO, grass pea amine oxidase; LSAO, lentil amine oxidase; OPAO, oat polyamine oxidase; PAO, polyamine oxidase

\section{Introduction}

Polyamines (i.e. putrescine, spermidine and spermine) are ubiquitous cationic compounds, which are involved in crucial physiological events including cell growth and differentiation. Polyamine levels are controlled through biosynthetic and biodegradation pathways ${ }^{1}$. The oxidative degradation of polyamines is catalyzed by quinoprotein copper-containing amine oxidases (CAOs, EC 1.4.3.6) and flavoprotein polyamine oxidases (PAOs, EC 1.5.3.11) ${ }^{1}$. As it is considered in the classification, CAOs attack primary amino groups of substrates, whereas PAOs attack secondary amino groups. In plants, CAOs preferentially oxidize diamines like putrescine or cadaverine and from that reason they are often called diamine oxidases ${ }^{2}$. The oxidative deamination of CAO substrates results in the corresponding aldehydes, ammonium ions and hydrogen peroxide ${ }^{2}$. PAOs catalyze the oxidative cleavage of spermine and spermidine at their secondary amino groups. Plant PAOs produce 4-aminobutanal (from spermidine) or $\mathrm{N}$-(3aminopropyl)-4-aminobutanal (from spermine), hydrogen peroxide and 1,3-propanediamine ${ }^{3}$. Representative members of the enzymes were crystallized and thoroughly characterized with respect to structure-functional relationships ${ }^{4}$.

A<smiles>NCCOCCOCCN</smiles>

B

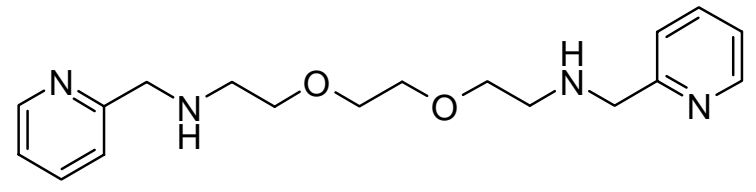

Figure 1. Chemical structures of the studied compounds. (A) 1,8-diamino-3,6-dioxaoctane (DADO); (B) 1,10-bis(2-pyridinylmethyl)-4,7-dioxa-1,10-diazadecane (BPDD).

Various synthetic polyamine analogs and polyamine derivatives have been reported as substrates or inhibitors of amine oxidases ${ }^{5}$. Such compounds represent important tools in the study of catalytic properties of the enzymes and they often find applications in physiological research $^{6}$. We synthesized two polyamine analogs comprising ether groups: 1,8-diamino-3,6dioxaoctane (DADO) and 1,10-bis(2-pyridinylmethyl)-4,7-dioxa-1,10-diazadecane (BPDD); see Figure 1. DADO is often used as a bifunctional reactant in condensation reactions producing 
macrocyclic compounds ${ }^{7}$. Similar applications in organic syntheses have been described for various analogs of BPDD, where the 2-pyridylmethyl moieties are replaced by benzyls, furfuryls, 2-methoxyethyls etc. Such substituents are converted into side arms in macrorings formed by condensation with 1,2-bis(2-iodoethoxy)ethane ${ }^{8}$. In this work, DADO and BPPD were tested for their interaction with plant amine oxidases. If enzymatic oxidation to the corresponding aldehydes would occur, it might initiate intramolecular or intermolecular cyclizations resulting in heterocyclic compounds. It should be noted in this context that the diaminoether 1,5-diamino-3oxapentane is known as a good substrate of plant CAOs, which is converted to a dihydrooxazine ${ }^{9}$. Indeed, DADO was readily oxidized by plant CAOs. However, mass spectrometric analysis of the reaction mixture demonstrated that no cyclic product was formed. BPDD was not oxidized at all, but it provided a competitive inhibition. In case of plant PAO, both studied compounds were found to be competitive inhibitors showing only weak inhibition potency.

\section{Results and Discussion}

Amine oxidase assay used in this study is based on the formation of hydrogen peroxide by substrate oxidation, which is immediately utilized by peroxidase in the coupled detecting reaction. In this way, DADO was recognized as a substrate of plant CAOs. Relative rate of its oxidation (at a saturating concentration of $2.5 \mathrm{mM}$ ) by grass pea amine oxidase (GPAO) was $20 \%$ when that of putrescine oxidation was taken as $100 \%$. This ratio was similar to those for 1,6-hexanediamine (29\%), 1,7-heptanediamine (14\%) and 1,8-octanediamine (10\%). For the enzymes from lentil seedlings (LSAO) and Euphorbia characias latex (ELAO), the relative rates of DADO oxidation were 15 and $8 \%$, respectively. Stoichiometry of the reaction was determined by oxygen consumption. In all three cases, 1 mol of oxygen was consumed per $1 \mathrm{~mol}$ of substrate, which is in agreement with a general scheme of CAO reaction ${ }^{2}$. The following Michaelis-Menten constant $\left(K_{\mathrm{m}}\right)$ values for DADO of GPAO, LSAO and ELAO were determined: $0.15,0.36$ and $1.05 \mathrm{mM}$, respectively. Such values correspond well with those for the best natural diamine substrates of plant CAOs - putrescine, cadaverine and spermidine ${ }^{10}$. Using Britton-Robinson buffers for activity assay ( $\mathrm{pH}$ range 5.0-9.0), an optimal $\mathrm{pH}$ value of 7.5 was found for DADO oxidation. Based on the above characteristics, DADO can be considered a good substrate of the enzymes, which have long been known for their broad substrate specificity. 


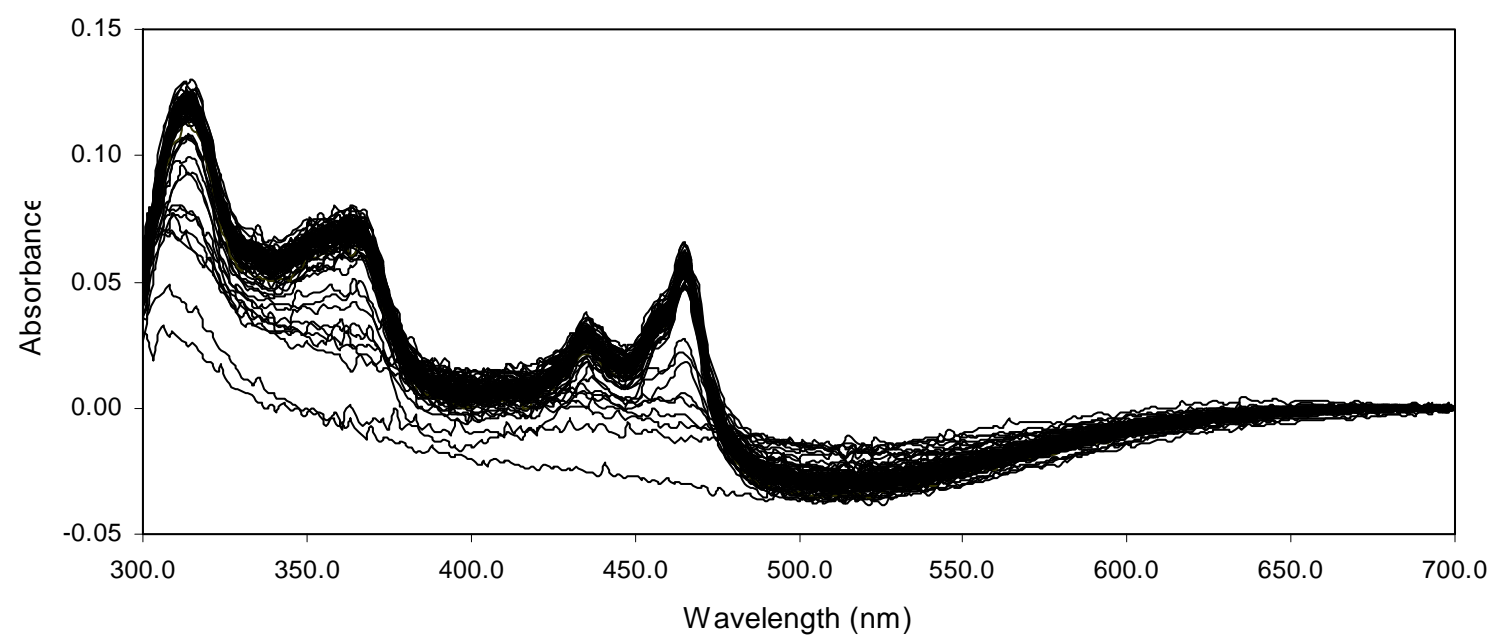

Figure 2. Absorption spectroscopy of GPAO reaction with DADO. Figure shows difference absorption spectra of the interaction of native GPAO $(20 \mu \mathrm{M})$ with DADO $(1.0 \mathrm{mM})$ in air saturated $20 \mathrm{mM}$ potassium phosphate buffer, $\mathrm{pH}$ 7.0. The spectra were recorded immediately after mixing the reagents in $100-\mathrm{ms}$ intervals for $10 \mathrm{~s}$ at $30^{\circ} \mathrm{C}$.

Visible spectra of plant CAOs show a broad absorption band centered at $500 \mathrm{~nm}$ reflecting the presence of the topaquinone cofactor ${ }^{11}$. Aerobic addition of a substrate to the enzyme is followed by rapid disappearance of the cofactor absorption, which slowly reappears after the substrate exhaustion. A stable yellow intermediate, the $\mathrm{Cu}(\mathrm{I})$-semiquinolamine radical, is observable in anaerobiosis, when the reaction is initiated by substrate addition. By means of rapid scanning, the radical spectrum can be recorded also under admission of air ${ }^{12}$. Figure 2 presents absorption spectra recorded in aerobiosis within first $10 \mathrm{~s}$ after rapid mixing of GPAO with DADO in potassium phosphate buffer, $\mathrm{pH}$ 7.0. The time delay of each successive spectrum was $100 \mathrm{~ms}$. Absorption maxima at 365, 436 and $465 \mathrm{~nm}$ are clearly distinguished, which are characteristic for substrate-reduced CAOs. They indicate fast formation of the cofactor radical ${ }^{11}$. The peak at $315 \mathrm{~nm}$ can be assigned to the $\mathrm{Cu}$ (II)-aminoresorcinol form of the cofactor, which is in equilibrium with the $\mathrm{Cu}(\mathrm{I})$-semiquinolamine radical in the presence of air $^{12}$. Similar results were also obtained for LSAO and ELAO. 


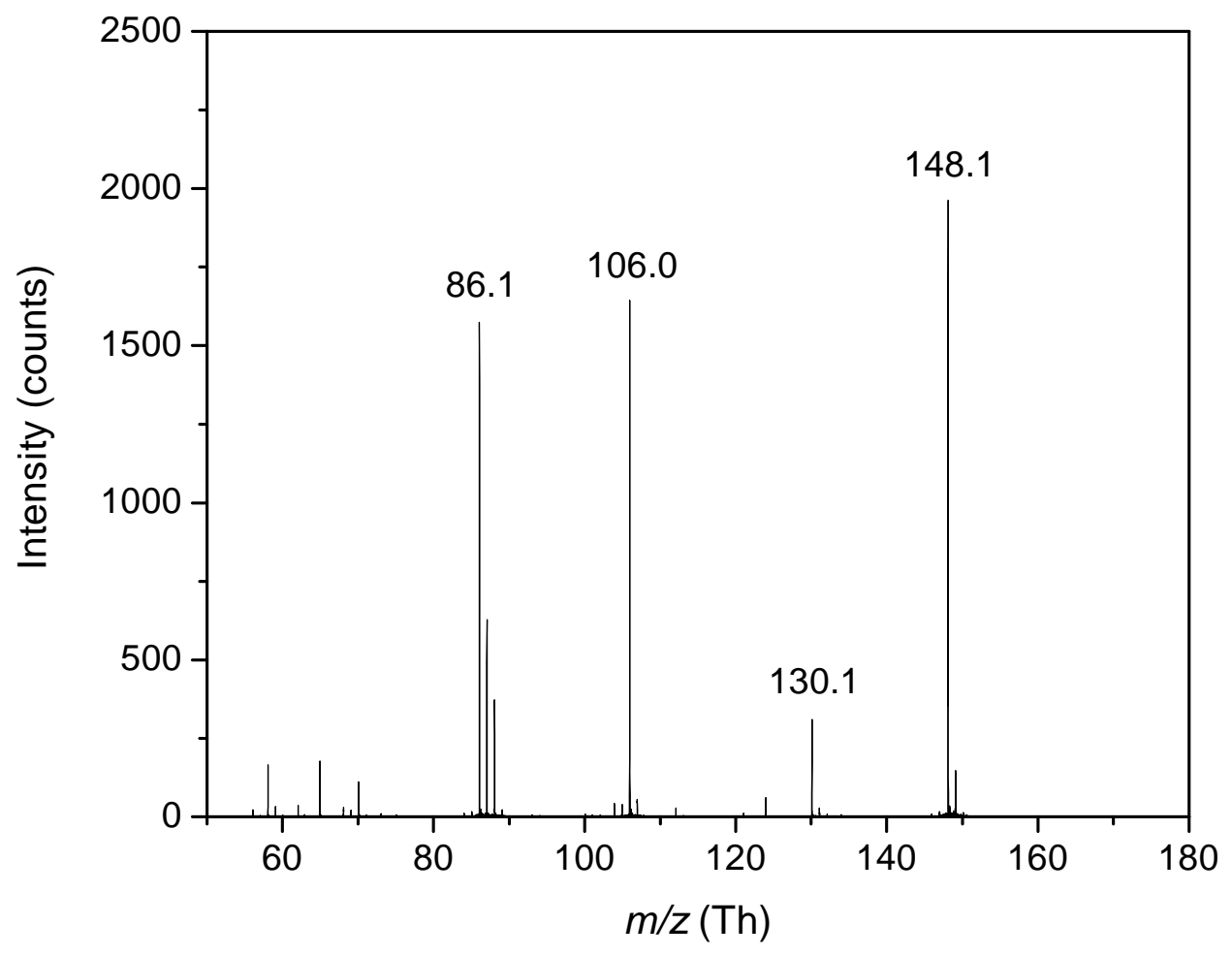

Figure 3. Tandem mass spectrometric (MS/MS) analysis of DADO oxidation product. DADO oxidation by an excess of GPAO was performed in $50 \mathrm{mM}$ ammonium bicarbonate at $37{ }^{\circ} \mathrm{C}$ for 12h. After removing the enzyme by ultrafiltration, the reaction mixture was analyzed by electrospray-ionization mass spectrometry. The spectrum shown was recorded after collisioninduced fragmentation of the parent ion belonging to the DADO oxidation product $(\mathrm{m} / z$ 148.1; $\left.[\mathrm{M}+\mathrm{H}]^{+}-\mathrm{C}_{6} \mathrm{H}_{14} \mathrm{NO}_{3}{ }^{+}\right)$. The observed fragment ions: $m / z$ 130.1 $\left(\mathrm{C}_{6} \mathrm{H}_{12} \mathrm{NO}_{2}{ }^{+}\right), m / z 106.1$ $\left(\mathrm{C}_{4} \mathrm{H}_{12} \mathrm{NO}_{2}{ }^{+}\right), m / z 86.1\left(\mathrm{C}_{4} \mathrm{H}_{8} \mathrm{NO}^{+}\right)$.

The aminoaldehyde products of putrescine, cadaverine and spermidine oxidation by plant CAOs spontaneously cyclize to $\Delta^{1}$-pyrroline, $\Delta^{1}$-piperideine and 1,5-diaza-bicyclononane, respectively ${ }^{11}$. Mass spectrometric analysis of GPAO/DADO reaction mixture revealed the presence of a reaction product with $m / z 148$, whose MS/MS fragmentation pattern (Figure 3) was consistent with the structure of 8-amino-3,6-dioxaoctanal. No peaks, which would indicate spontaneous cyclization or polymerization of the aldehyde were found in the mass spectrum. This is in contrast to the oxidation of 1,5-diamino-3-oxapentane as a related diaminoether compound, where the corresponding oxidation product undergoes intramolecular cyclization and loses water to form 3,6-2H-1,4-dihydrooxazine ${ }^{9}$. It seems that an intramolecular cyclization of 8amino-3,6-dioxaoctanal to a dioxazonine derivative or condensations to larger polymers are unfavorable. Cyclization did not occur even after heating of the reaction mixture (after $12 \mathrm{~h}$ incubation at $37{ }^{\circ} \mathrm{C}$ ) at $50{ }^{\circ} \mathrm{C}$ for $30 \mathrm{~min}$. 


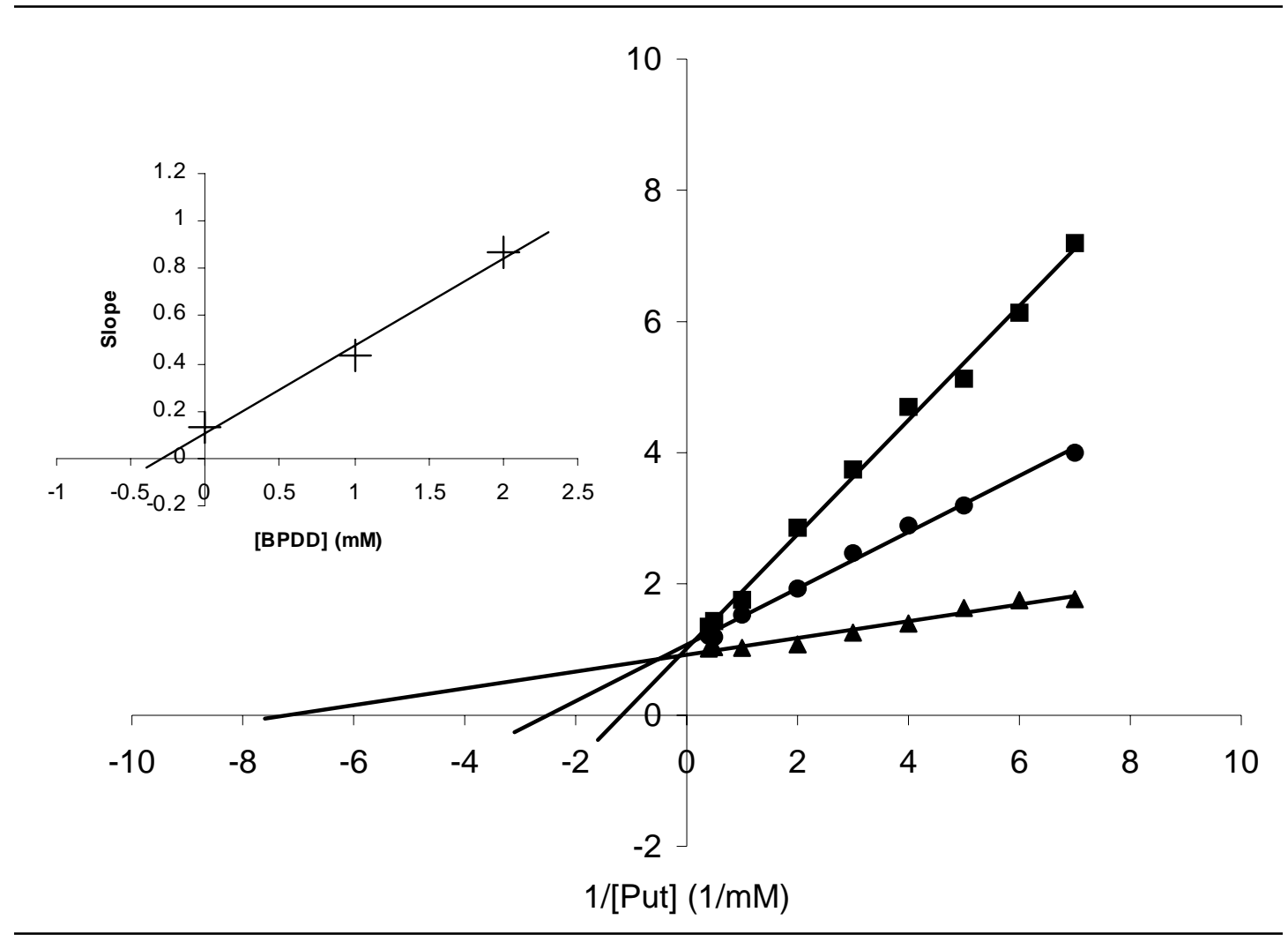

Figure 4. Double reciprocal plot of competitive inhibition of GPAO by BPDD. Putrescine (Put) was a substrate. Initial rates were determined by the guaiacol spectrophotometric method ${ }^{20}$. The assay was carried out in $0.1 \mathrm{M}$ potassium phosphate buffer, $\mathrm{pH} 7.0$, at $30{ }^{\circ} \mathrm{C}$. BPDD concentrations were as follows: $\boldsymbol{\Delta}-0, \bullet-1.0$ and $-2.0 \mathrm{mM}, K_{\mathrm{i}}=0.28 \mathrm{mM}$; y-axis represents the reciprocal absorbance values. The inset shows secondary plot of slopes against the inhibitor concentration.

BPDD was not oxidized at all by GPAO. In order to look for another effects on the enzyme, the compound was tested as an inhibitor towards the substrate putrescine. Figure 4 illustrates an experiment for the determination of inhibitory properties of the compound. As can be seen from the Lineweaver-Burk plot, BPDD functions as a weak competitive inhibitor of the enzyme and it is characterized by an inhibition constant $\left(K_{\mathrm{i}}\right)$ value of $0.28 \mathrm{mM}$. Inhibitors of plant CAOs have been recently reviewed ${ }^{13}$. The most potent competitive inhibitors show $K_{\mathrm{i}}$ values of $10^{-7}-10^{-6} \mathrm{M}$ (diaminoketones).

Plant PAOs are more specific than CAOs. Usually they oxidize only spermine and spermidine. For some enzymes (e. g. maize PAO), a limited number of other substrates (polyamine derivatives) is $\mathrm{known}^{14}$. Oat seedling PAO (OPAO) did not utilize DADO and BPDD as substrates. OPAO interaction with DADO was found to produce a weak competitive inhibition towards the substrate spermidine. The inhibition was characterized by a relatively high $K_{\mathrm{i}}$ value of $1.6 \mathrm{mM}$. This is surprising when we realize that diamines with 6 to 10 carbon atoms 
are known as powerful competitive inhibitors of maize PAO with $K_{\mathrm{i}}$ values of $10^{-7}-10^{-6} \mathrm{M}^{15}$. As can be seen in the crystal structure of maize PAO, the active site consists of a „U-shaped“ tunnel, which passes through the protein molecule. Polyamine substrates or efficient PAO inhibitors bind at the active site and their molecules are bent to accommodate the tunnel shape ${ }^{15}$. Probably DADO is not flexible enough to compete with the natural substrate spermidine used for the inhibition assay. BPDD also inhibited OPAO in a competitive manner. The inhibition was moderate $\left(K_{\mathrm{i}}=0.58 \mathrm{mM}\right)$ though the terminal pyridinyl substituents could mediate a hydrophobic or ionic interaction facilitating the binding. Interestingly, $N, N^{\prime}$-bis(benzyl)polyamine analogs derived by binding benzylaminopropyl groups to nitrogens of $\mathrm{C} 4-\mathrm{C} 10$ diamines have already been described as substrates for a mammalian $\mathrm{PAO}^{16}$.

In conclusion, we describe interactions of two synthetic diaminoether compounds with representatives of plant CAOs and PAOs. Whereas BPPD was recognized as a weak competitive inhibitor of the enzymes, the second studied compound - DADO - provided a different result. Plant CAOs accept DADO as a good substrate, plant PAOs are weakly inhibited by the compound. From that reason, we suggest possible DADO application as a ligand for affinity separation, which might selectively discriminate CAOs from PAOs in plant extracts. This suggestion comes from the fact that similarly based 6-aminohexyl-Sepharose has been successfully used for the isolation of LSAO and ELAO ${ }^{17}$.

\section{Experimental Section}

Chemicals. 2-Pyridinecarboxaldehyde was from Acros (Geel, Belgium). 1,2Bis(chloroethoxy)ethane, deuterium oxide (99.96\%), deuterated dimethyl sulfoxide (99.96\%), DMF, potassium phthalimide and sodium borohydride were from Sigma-Aldrich Chemie (Steinheim, Germany). A hydrogen chloride solution in isopropanol was provided by Dr. Zatloukal, Laboratory of Growth Regulators, Faculty of Science, Palacký University. All other chemicals including ethanol (96\%) were of analytical purity grade.

Enzymes. Grass pea (Lathyrus sativus) seedling amine oxidase (GPAO) was obtained as already described $^{10}$. Amine oxidases from lentil seedlings (LSAO) and Euphorbia characias latex (ELAO) were purified according to previously published protocols ${ }^{17}$. The purified enzymes were stored frozen at $-80{ }^{\circ} \mathrm{C}$. Oat seedling polyamine oxidase (OPAO) was isolated as recently published $^{18}$. Horseradish (Armoracia rusticana) peroxidase was purchased from Sigma-Aldrich Chemie.

Instruments. NMR measurements were performed at $25{ }^{\circ} \mathrm{C}$ on a Bruker AVANCE 300 NMR spectrometer (Bruker BioSpin, Rheinstetten, Germany), operating at a magnetic field strength of 7.05 T. Mass spectra were acquired on a Quattro micro ${ }^{\mathrm{TM}}$ triple-stage quadrupole mass spectrometer (Micromass, Manchester, UK) equipped with an electrospray ion source. Positive ionization mode was used producing protonated quasimolecular ions $\left([\mathrm{M}+\mathrm{H}]^{+}\right)$. All samples were directly introduced to the mass spectrometer by a syringe (flow rate of $10 \mu 1 \mathrm{~min}^{-1}$ ). 
Parameters of the electrospray were as follows: capillary voltage $3.0 \mathrm{kV}$, cone voltage $30.0 \mathrm{~V}$, desolvation gas flow $550 \mathrm{~L} \mathrm{~h}^{-1}$, desolvation temperature $350{ }^{\circ} \mathrm{C}$, source temperature $100{ }^{\circ} \mathrm{C}$. Full scan spectra were obtained by scanning mass range $50-400 \mathrm{amu}(0.7 \mathrm{~s}$ per scan). Tandem mass spectra (daughter ion scan mode) were obtained by scanning mass range from 50 to $\mathrm{m} / \mathrm{z}$ of appropriate parent ion. Collision cell pressure was kept between 3.0 and 3.5 mbar with argon gas and collision cell energy was $25 \mathrm{eV}$. Elemental analyses were carried out using a combustion elemental analyzer Finnigan Flash EA1112 (Thermo Electron Corporation, San Jose, CA, USA). Melting points were measured using an SMP 3 apparatus for glass sample capillaries (Stuart Scientific, Redhill, Surrey, UK).

Compound characterization. 1,8-Diamino-3,6-dioxaoctane (DADO) was prepared by the Gabriel synthesis. According to a common procedure ${ }^{19}$, 1,2-bis(chloroethoxy)ethane (9.4 g, 50 mmol) was added dropwise with stirring at $0-5{ }^{\circ} \mathrm{C}$ to a suspension of potassium phthalimide $(20.8 \mathrm{~g}, 110 \mathrm{mmol})$ in $70 \mathrm{~mL}$ of DMF over $15 \mathrm{~min}$. The suspension was then heated for $3 \mathrm{~h}$ at $100^{\circ} \mathrm{C}$, cooled, and poured into $1 \mathrm{~L}$ of ice-cold water. Filtration of the white solid and washing with water gave the intermediate bisphthalimide. A solution of this material (melting point 178$179^{\circ} \mathrm{C}$ ) in $50 \mathrm{~mL}$ of acetic acid and $50 \mathrm{~mL}$ of concentrated $\mathrm{HCl}$ was heated under reflux for 65 h. The precipitated phthalic acid was removed by filtration, the filtrate was concentrated to a volume of $10 \mathrm{~mL}$ in vacuo, and $250 \mathrm{~mL}$ of warm ethanol was added. Upon cooling, DADO dihydrochloride crystallized ( $7.8 \mathrm{~g}, 71 \%$ ). The compound was recrystallized by dissolving in hot ethanol, filtration with charcoal and precipitation in refrigerator. ${ }^{1} \mathrm{H}-\mathrm{NMR}\left(300 \mathrm{MHz}, \mathrm{D}_{2} \mathrm{O}\right): 3.15$ (t, $\left.4 \mathrm{H}, J=5.1, \mathrm{CH}_{2} \mathrm{~N}\right), 3.66\left(\mathrm{~s}, 4 \mathrm{H}, \mathrm{OCH}_{2} \mathrm{CH}_{2} \mathrm{O}\right), 3.70\left(\mathrm{t}, 4 \mathrm{H}, J=5.1, \mathrm{OCH}_{2} \mathrm{CH}_{2} \mathrm{~N}\right)$ ppm. ${ }^{13} \mathrm{C}-\mathrm{NMR}$ $\left(75 \mathrm{MHz}, \mathrm{D}_{2} \mathrm{O}\right): 39.1\left(\mathrm{CH}_{2} \mathrm{~N}\right), 66.4\left(\mathrm{OCH}_{2} \mathrm{CH}_{2} \mathrm{~N}\right), 69.6\left(\mathrm{OCH}_{2} \mathrm{CH}_{2} \mathrm{O}\right)$ ppm. Elemental composition for $\mathrm{C}_{6} \mathrm{H}_{16} \mathrm{~N}_{2} \mathrm{O}_{2} .2 \mathrm{HCl}$ : C $32.80 \%, \mathrm{H} 7.97 \%, \mathrm{~N} 12.21 \%$ (experimental values), $\mathrm{C}$ $32.59 \%, \mathrm{H} 8.20 \%, \mathrm{~N} 12.67 \%$ (calculated values). ESI-MS: $m / z 149\left([\mathrm{M}+\mathrm{H}]^{+}-\mathrm{C}_{6} \mathrm{H}_{17} \mathrm{~N}_{2} \mathrm{O}_{2}{ }^{+}\right)$; MS/MS: $m / z 106\left(\mathrm{C}_{4} \mathrm{H}_{12} \mathrm{NO}_{2}{ }^{+}\right), 88\left(\mathrm{C}_{4} \mathrm{H}_{10} \mathrm{NO}^{+}\right), 70\left(\mathrm{C}_{4} \mathrm{H}_{6} \mathrm{O}^{+}\right)$. Melting point was $114-115{ }^{\circ} \mathrm{C}$. Free base of DADO (a transparent oil) was prepared by hydrazinolysis ${ }^{19}$ of the above bisphthalimide reaction intermediate.

1,10-Bis(2-pyridinylmethyl)-4,7-dioxa-1,10-diazadecane (BPDD) was synthesized by reductive alkylation of DADO. 2-Pyridinecarboxaldehyde $(5.6 \mathrm{~g}, 52.5 \mathrm{mmol})$ was added dropwise to a solution of DADO ( $3.7 \mathrm{~g}$ of free base, $25 \mathrm{mmol}$ ) in $25 \mathrm{~mL}$ of methanol and the mixture was heated under reflux for $6 \mathrm{~h}$. After cooling to $25^{\circ} \mathrm{C}, \mathrm{NaBH}_{4}(2.7 \mathrm{~g}, 70 \mathrm{mmol})$ was added in small portions and the mixture was stirred for $16 \mathrm{~h}$. The reaction was quenched by careful addition of $4 \mathrm{M} \mathrm{HCl}$ until a strongly acidic $\mathrm{pH}$ was reached and the mixture was stirred for an additional 30 min. Then the solution was made basic using ammonia (12.5\% in water), extracted with $\mathrm{CH}_{2} \mathrm{Cl}_{2}$ $(3 \times 50 \mathrm{ml})$ and the combined organic layers were dried $\left(\mathrm{Na}_{2} \mathrm{SO}_{4}\right)$. Crude product was obtained as a yellow oil after evaporation of the solvent under reduced pressure. The product oil was purified by column chromatography on silica gel as decribed for a similar dibenzyl derivative ${ }^{7}$. BPDD tetrahydrochloride was obtained by adding an excess of hydrogen chloride in isopropanol and recovered by filtration $(6.9 \mathrm{~g}, 58 \%)$. Recrystallization of the final product was performed by dissolving in hot ethanol, filtration with charcoal, cooling on ice and careful adding of ice-cold 
diethylether. BPDD solution in water showed an absorption maximum at $260 \mathrm{~nm}$ revealing the presence of pyridine moiety. ${ }^{1} \mathrm{H}-\mathrm{NMR}\left(300 \mathrm{MHz}, \mathrm{d}_{6}-\mathrm{DMSO}\right): 3.09$ (t, 4H, J=5.0 Hz, CH${ }_{2} \mathrm{~N}$ ), $3.61\left(\mathrm{~m}, 8 \mathrm{H}, \mathrm{CH}_{2} \mathrm{OCH}_{2} \mathrm{CH}_{2} \mathrm{OCH}_{2}\right.$ ), 3.82 (s, 4H, 2-pyridinylmethyl $\mathrm{CH}_{2}$ ), 7.41 (m, 2H, CH-Py), 7.60 (d, 2H, J=7.9 Hz, CH-Py), 7.89 (m, 2H, CH-Py), 8.59 (d, 2H, J=4.8 Hz, CH-Py) ppm. ${ }^{13} \mathrm{C}-$ NMR (75 MHz, d 6 -DMSO): $48.6\left(\mathrm{CH}_{2} \mathrm{~N}\right), 59.1$ (2-pyridinylmethyl $\left.\mathrm{CH}_{2}\right), 65.5\left(\mathrm{OCH}_{2} \mathrm{CH}_{2} \mathrm{~N}\right)$, $69.5\left(\mathrm{OCH}_{2} \mathrm{CH}_{2} \mathrm{O}\right), 125.4$ (CH-Py), 125.6 (CH-Py), 140.9 (CH-Py), 149.8 ( $\left.C \mathrm{H}-\mathrm{Py}\right), 156.8$ (CPy) ppm. Elemental composition for $\mathrm{C}_{18} \mathrm{H}_{26} \mathrm{~N}_{4} \mathrm{O}_{2} .4 \mathrm{HCl}$ : C $45.22 \%, \mathrm{H} 6.30 \%, \mathrm{~N} 12.01 \%$ (experimental values), C 45.39\%, H 6.35\%, N 11.76\% (calculated values). ESI-MS: $\mathrm{m} / z 331$ $\left([\mathrm{M}+\mathrm{H}]^{+}-\mathrm{C}_{18} \mathrm{H}_{27} \mathrm{~N}_{4} \mathrm{O}_{2}{ }^{+}\right)$; MS/MS: $m / z 197\left(\mathrm{C}_{10} \mathrm{H}_{17} \mathrm{~N}_{2} \mathrm{O}_{2}{ }^{+}\right), 179\left(\mathrm{C}_{10} \mathrm{H}_{15} \mathrm{~N}_{2} \mathrm{O}^{+}\right), 135\left(\mathrm{C}_{8} \mathrm{H}_{11} \mathrm{~N}_{2}{ }^{+}\right)$, $92\left(\mathrm{C}_{6} \mathrm{H}_{6} \mathrm{~N}^{+}\right)$. Melting with decomposition was at $183{ }^{\circ} \mathrm{C}$.

Enzyme assays. Amine oxidase activity was determined by spectrophotometer using a coupled reaction with horseradish peroxidase and guaiacol; putrescine served as a substrate ${ }^{20}$. The method was also applied for polyamine oxidase; spermidine was a substrate in this case $(1 \mathrm{mM}$ final concentration). Both assays were performed at $30{ }^{\circ} \mathrm{C}$ in a thermostated cell. For inhibition measurements, the reaction mixture was pipetted as follows: $1.50 \mathrm{~mL}$ of $0.117 \mathrm{M}$ potassium phosphate buffer, $\mathrm{pH} 7.0,25 \mu \mathrm{L}$ of $35 \mathrm{mM}$ guaiacol, $25 \mu \mathrm{L}$ of $5 \mu \mathrm{M}$ horseradish peroxidase (2500 nkat mg-1), $10 \mu \mathrm{L}$ of diluted enzyme and $140 \mu \mathrm{L}$ of inhibitor (in a proper dilution to get desired concentration). The reaction was initiated by the addition of substrate $(50 \mu \mathrm{L})$. The mixture was continually stirred and monitored by increasing absorbance at $436 \mathrm{~nm}$. Inhibition constants were calculated from Lineweaver-Burk plots constructed by linear regression of the measured data (three different measurements) using the computer program Microsoft Excel 2002. Protein content was determined using the spectrophotometric method with bicinchoninic acid; BSA served as a standard ${ }^{21}$. Rapid-scan absorption spectroscopy of the reaction mixture in the early phase of GPAO reaction with DADO was performed according to described methodology ${ }^{12}$. For mass spectrometric analysis of oxidation products, $20 \mathrm{mM}$ DADO in $50 \mathrm{mM}$ ammonium bicarbonate was incubated with an excess of GPAO or LSAO at $37^{\circ} \mathrm{C}$ for $12 \mathrm{~h}$. Then the mixture was ultrafiltrated using a $10 \mathrm{kDa}$ cut-off Centricon filter units (Millipore, Bedford, MA, USA) and the filtrate injected for analysis. Reaction stoichiometry was analyzed as described $^{22}$.

\section{Acknowledgements}

The authors gratefully acknowledge financial help of the grant MSM 6198959216 from the Ministry of Education, Youth and Sports, Czech Republic. Dr. Igor Popa from Laboratory of Growth Regulators, Palacký University, is thanked for performing NMR analyses. 


\section{References}

1. (a) Bouchereau, A.; Aziz, A.; Larher, F.; Martin-Tanguy, J. Plant Sci. 1999, 140, 103. (b) Cona, A.; Rea, G.; Angelini, R.; Federico, R.; Tavladoraki, P. Trends Plant Sci. 2006, 11, 80 .

2. Frébort, I.; Adachi, O. J. Ferment. Bioeng. 1995, 80, 625.

3. Šebela, M.; Radová, A.; Angelini, R.; Tavladoraki, P.; Frébort, I.; Peč, P. Plant Sci. 2001, 160, 197.

4. (a) Kumar, V.; Dooley, D. M.; Freeman, H. C.; Guss, J. M.; Harvey, I.; McGuirl, M. A.; Wilce, M. C. J.; Zubak, V. M. Structure 1996, 4, 943. (b) Binda, C.; Coda, A.; Angelini, R.; Federico, R.; Ascenzi, P.; Mattevi, A. Structure 1999, 7, 265.

5. (a) Peč, P.; Frébort, I. Eur. J. Biochem. 1992, 209, 661. (b) Shepard, E. M.; Smith, J.; Elmore, B. O.; Kuchar, J. A.; Sayre, L. M.; Dooley, D. M. Eur. J. Biochem. 2002, 269, 3645. (c) Bianchi, M.; Polticelli, F.; Ascenzi, P.; Botta, M.; Federico, R.; Mariottini, P.; Cona, A. FEBS J. 2006, 273, 1115.

6. (a) Ha, H. C.; Woster, P. M.; Yager, J. D.; Casero, R. A. Jr. Proc. Natl. Acad. Sci. USA 1997, 94, 11557. (b) Burns, M. R.; LaTurner, S.; Ziemer, J.; McVean, M.; Devens, B.; Carlson, C. L.; Graminski, G. F.; Vanderwerf, S. M.; Weeks, R. S.; Carreon J. Bioorg. Med. Chem. Lett. 2002, 12, 1263.

7. Teyssot, M.-L.; Fayolle, M.; Philouze, C.; Dupuy, C. Eur. J. Org. Chem. 2003, 1, 54.

8. Gatto, V. J.; Arnold, K. A.; Viscariello, A. M.; Miller, S. R.; Morgan; C. R., Gokel, G. W. J. Org. Chem. 1986, 51, 5373.

9. (a) Cragg, J. E.; Herbert, R. B.; Kgaphola, M. Tetrahedron Lett. 1990, 47, 6907. (b) Šebela, M.; Lamplot; Z., Petřivalský, M.; Kopečný, D.; Lemr, K.; Frébort, I.; Peč, P. Biochim. Biophys. Acta 2003, 1647, 355.

10. Šebela, M.; Luhová, L.; Frébort, I.; Faulhammer, H. G.; Hirota, S.; Zajoncová, L.; Stužka, V.; Peč, P. Phytochem. Anal. 1998, 9, 211.

11. Medda, R.; Padiglia, A.; Floris, G. Phytochemistry 1995, 39, 1.

12. Šebela, M.; Frébort, I.; Lemr, K.; Brauner, F.; Peč, P. Arch. Biochem. Biophys. 2000, 384, 88.

13. Padiglia, A.; Medda, R.; Pedersen, J. Z.; Lorrai, A.; Peč, P.; Frébort, I.; Floris, G. J. Enzym. Inhib. 1998, 13, 311.

14. Federico, R.; Ercolini, L.; Laurenzi, M.; Angelini, R. Phytochemistry 1996, 43, 339.

15. Cona, A.; Manetti, F.; Leone, R.; Corelli, F.; Tavladoraki, P.; Polticelli, F.; Botta, M. Biochemistry 2004, 43, 3426.

16. Bitonti, A. J.; Dumont, J. A.; Bush, T. L.; Stemerick, D. M.; Edwards, M. L.; McCann, P. P. J. Biol. Chem. 1990, 265, 382-388.

17. (a) Floris, G.; Giartosio, A.; Rinaldi, A. Phytochemistry 1983, 22, 1871. (b) Padiglia, A.; Medda, R.; Lorrai, A.; Murgia, B.; Pedersen, J. Z.; Finazzi Agró, A.; Floris, G. Plant Physiol. 1998, 117, 1363. 
18. Stránská, J.; Šebela, M.; Tarkowski, P.; Řehulka, P.; Chmelík, J.; Popa, I.; Peč, P. Biochimie 2006, in press.

19. He, Z.; Nadkarni, D. V.; Sayre, L. M.; Greenaway, F. T. Biochim. Biophys. Acta 1995, 1253, 117.

20. (a) Frébort, I.; Haviger, A.; Peč, P. Biológia (Bratislava) 1989, 44, 729. (b) Smith, T. A. Methods Enzymol. 1983, 94, 311.

21. Smith, P. K.; Krohn, R. I.; Hermanson, G. T.; Mallia, A. K.; Gartner, F. H.; Provenzano, M. D.; Fujimoto, E. K.; Goeke, N. M.; Olson, B. J.; Klenk, D. C. Anal. Biochem. 1985, 150, 76.

22. Lamplot, Z.; Šebela, M.; Fryčák, P.; Longu, S.; Padiglia, A.; Medda, R.; Floris, G.; Peč, P. J. Enzym. Inhib. Med. Chem. 2005, 20, 143. 